\title{
Influence of Zinc Chelates on Yield and Zn Uptake by Maize
}

\author{
P. Malathi* \\ Department of Natural Resources Management, Horticultural College and Research Institute, \\ Periyakulam, Tamil Nadu, India \\ *Corresponding author
}

Keywords

Maize, Zinc

chelates, Yield,

Zinc uptake

Article Info

Accepted:

04 December 2020

Available Online:

10 January 2021
New chelated Zn formulations TNAU Zn EDTA $(9.7 \% \mathrm{Zn})$ and TNAU Zn citrate $(9.0 \%$ $\mathrm{Zn}$ ) were developed and tested in comparison with $\mathrm{ZnSO}_{4}$ and commercial $\mathrm{Zn}$ EDTA in a field experiment with maize crop conducted during 2018-19 at Tamil Nadu Agricultural University, Coimbatore. The experiment was laid out in Randomized Block Design with treatments control (NPK alone), soil application of $7.5 \mathrm{~kg} \mathrm{Zn} \mathrm{ha}^{-1}$ as $\mathrm{ZnSO}_{4}, 0.75$ and 1.5 $\mathrm{kg} \mathrm{Zn} \mathrm{ha-1} \mathrm{as} \mathrm{TNAU} \mathrm{Zn} \mathrm{EDTA,} \mathrm{TNAU} \mathrm{Zn} \mathrm{citrate} \mathrm{and} \mathrm{commercial} \mathrm{Zn} \mathrm{EDTA,} \mathrm{foliar} \mathrm{spray}$ of $0.5 \% \mathrm{ZnSO}_{4}$, TNAU Zn EDTA, TNAU Zn citrate and commercial Zn EDTA thrice on 30,40 and 50 days after sowing (DAS). Significantly highest grain yield (7158 kg ha ${ }^{-1}$ ) and stover yield $\left(12741 \mathrm{~kg} \mathrm{ha}^{-1}\right)$ were recorded in the treatment foliar spray of $0.5 \%$ TNAU Zn EDTA which remained on par with the application of $1.5 \mathrm{~kg} \mathrm{Zn} \mathrm{ha}^{-1}$ as TNAU Zn EDTA, foliar spray of $0.5 \%$ TNAU Zn citrate and foliar spray of $0.5 \%$ commercial $\mathrm{Zn}$ EDTA. Foliar spray of $0.5 \%$ TNAU Zn citrate registered grain yield of $6962 \mathrm{~kg} \mathrm{ha}^{-1}$ and stover yield of $12115 \mathrm{~kg} \mathrm{ha}^{-1}$. Significantly highest grain $\mathrm{Zn}$ content and uptake of $32.4 \mathrm{mg}$ $\mathrm{kg}^{-1}$ and207 $\mathrm{g} \mathrm{ha}^{-1}$ respectively were observed in the treatment foliar spray of $0.5 \%$ TNAU $\mathrm{Zn}$ citrate. Stover $\mathrm{Zn}$ content $\left(36.5 \mathrm{mg} \mathrm{kg}^{-1}\right)$ and uptake (436 $\mathrm{g} \mathrm{ha}^{-1}$ ) were significantly highest with foliar spray of $0.5 \%$ TNAU Zn EDTA. Percentage yield increase due to foliar spray of $0.5 \%$ TNAU Zn EDTA and $0.5 \%$ TNAU Zn citrate formulations were 12.3 and $9.17 \%$ respectively over $\mathrm{ZnSO}_{4}$ foliar spray. The treatments foliar spray of $0.5 \% \mathrm{TNAU}$ Zn EDTA and 0.5 \% TNAU Zn citrate thrice on 30, 40 and 50 DAS recorded higher grain and stover yield as well as $\mathrm{Zn}$ content and $\mathrm{Zn}$ uptake over all other treatments.

\section{Introduction}

Zinc deficiency in soil is increasing at an alarming rate due to intensive cropping and reduced use of organic manures. Coarse textured, calcareous, alkaline or sodic soils having sandy texture, high $\mathrm{pH}$ and low organic matter are generally deficient in available $\mathrm{Zn}$. $\mathrm{Zn}$ was one of the first micronutrients known to be essential for plants, animals and humans (Kabata- Pendias, 2000). Zinc plays a key role in various plant metabolic processes such as development of cell walls, respiration, carbohydrate metabolism and gene expression and regulation (Klug and Rhodes, 1987). Zn is a component of various enzymes involved in metabolic activities in plants. Plants grown on 
Zn deficient soils have reduced productivity and contain very low concentrations of $\mathrm{Zn}$ in the edible parts. $\mathrm{Zn}$ deficiency is a serious nutritional and health problem in human beings, especially in the developing countries where cereal-based foods are dominating the diet. Challenge for agricultural scientists is to feed the ever growing world population with nourishing food.

Zinc sulphate, the major source of zinc has the disadvantage of rapid convertibility. It is reported that chelated zinc shows higher use efficiency than zinc sulphate fertilizer and hence can be applied at 8 to 10 times less dose than their corresponding salts. A chelate is a kind of organic chemical complex in which the metal is held so tightly that it cannot be stolen by the other substances, which could convert it to an insoluble form. Chelates are considered the most effective fertilizers, compared to the inorganic forms, such as sulfates, which can react with $\mathrm{CaCO} 3$ forming low-solubility compounds (Loeppert, 1986; Vempati and Loeppert, 1988). Besides, the chelating agents increase the absorption of ions as the roots have more affinity for the chelated micronutrients. Chelated forms of $\mathrm{Zn}$ are more commonly used for foliar applications and have the advantage of being compatible with many herbicide and fungicide formulations in spray tank mixes, but they are more expensive than inorganic compounds (Alloway, 2008). An attempt was made to develop new chelated $\mathrm{Zn}$ formulations using EDTA and citric acid as chelating agents. The newly developed chelated $\mathrm{Zn}$ formulations were evaluated in a field experiment with maize crop.

\section{Materials and Methods}

The field experiment was conducted in $\mathrm{Zn}$ deficient soil at Eastern Block farm of Tamil Nadu Agricultural University, Coimbatore to evaluate newly developed chelated $\mathrm{Zn}$ formulations with maize (TNAU Maize hybrid CO6) as test crop. Newly developed TNAU Zn EDTA (9.7 \% Zn) and TNAU Zn citrate $(9.0 \% \mathrm{Zn})$ formulations were tested in comparison with $\mathrm{ZnSO}_{4}$ and commercial $\mathrm{Zn}$ EDTA. Treatments comprised of control (NPK alone), soil application of $7.5 \mathrm{~kg} \mathrm{Zn}$ $\mathrm{ha}^{-1}$ as $\mathrm{ZnSO}_{4}, 0.75$ and $1.5 \mathrm{~kg} \mathrm{Zn} \mathrm{ha}^{-1}$ as TNAU Zn EDTA,TNAU Zn citrate and commercial Zn EDTA, foliar spray of $0.5 \%$ $\mathrm{ZnSO}_{4}$, TNAU $\mathrm{Zn}$ EDTA,TNAU $\mathrm{Zn}$ citrate and commercial $\mathrm{Zn}$ EDTA thrice on 30, 40 and 50 days after sowing (DAS).

The field experiment was conducted in Randomized Block Design (RBD) with three replications. Soil Test Crop Response (STCR) based NPK fertilizer dose for Maize hybrid was worked out for a yield target of $9 \mathrm{t} \mathrm{ha}^{-1}$ andfertilizer $\mathrm{N}, \mathrm{P}_{2} \mathrm{O}_{5}$ and $\mathrm{K}_{2} \mathrm{O}$ applied were 259, 96 and $38 \mathrm{~kg} \mathrm{ha}^{-1}$ respectively. STCR based NPK was applied to all treatments.

Since the experimental soil was deficient in available $\mathrm{Fe}$, recommended dose of $\mathrm{FeSO}_{4}$, (50 $\mathrm{kg} \mathrm{ha}^{-1}$ ) was applied. Crop protection measures were taken up as and when needed. Plant samples were collected at late vegetative stage and harvest stage for assessing the $\mathrm{Zn}$ content and uptake. $\mathrm{Zn}$ content in plant samples was estimated using Atomic Absorption Spectrophotometer (Jackson, 1973). Grain and Stover yield were recorded. The data obtained were subjected to statistical analysis as suggested by Panse and Sukhatme (1978).

\section{Results and Discussion}

The physico chemical characteristics of experimental soil were analyzed and the results are presented in Table 1. The experimental soil belongs to Periyanaickenpalayam series and comes under the taxonomic classification fine, montmorillonitic, isohyperthermic, calcareous 
TypicHaplustert. The soil texture was clay loam. The soil was alkaline in reaction (8.07) with permissible amount of soluble salts $(0.24$

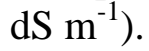

The experimental soil was calcareous. The organic carbon content of the soil was low (4.79 $\left.\mathrm{g} \mathrm{kg}^{-1}\right)$. The soil was low in available $\mathrm{N}$ $\left(134 \mathrm{~kg} \mathrm{ha}^{-1}\right)$, medium in available $\mathrm{P}(16.7 \mathrm{~kg}$ $\mathrm{ha}^{-1}$ ) and high in available $\mathrm{K}\left(657 \mathrm{~kg} \mathrm{ha}^{-1}\right)$. The soil was deficient in DTPA-Zn $(0.60 \mathrm{mg}$ $\left.\mathrm{kg}^{-1}\right)$, DTPA-Fe (2.27 $\left.\mathrm{mg} \mathrm{kg}^{-1}\right)$, DTPA-Cu $\left(0.89 \mathrm{mg} \mathrm{kg}^{-1}\right)$ and sufficient in DTPA-Mn (5.08 $\left.\mathrm{mg} \mathrm{kg}^{-1}\right)$.

\section{Grain and Stover Yield}

Regarding grain yield, significantly highest grain yield of $7158 \mathrm{~kg} \mathrm{ha}^{-1}$ was observed with foliar spray of $0.5 \%$ TNAU Zn EDTA $\left(\mathrm{T}_{10}\right)$ which was statistically on par with the soil application of $1.5 \mathrm{~kg} \mathrm{Zn} \mathrm{ha}^{-1}$ as TNAU Zn EDTA $\left(\mathrm{T}_{4}\right)$, foliar spray of $0.5 \%$ TNAU $\mathrm{Zn}$ citrate $\left(\mathrm{T}_{11}\right)$ and foliar spray of $0.5 \%$ commercial Zn EDTA $\left(\mathrm{T}_{12}\right)$ (Table 2). MacNacidhe and Fleming (1988) observed significant increase in grain yield due to foliar application of zinc in spring cereals and higher grain yield due to Zn EDTA than Zn sulphate. Similar to this result, Khalid et al.,
(2013) reported higher grain yield by the foliar application of $\mathrm{Zn} \mathrm{Ch:} \mathrm{EDTA} \mathrm{at} 180 \mathrm{~g}$ $\mathrm{Zn} \mathrm{ha}{ }^{-1}$ when compared to $\mathrm{ZnSO}_{4}$ and $\mathrm{Zn} \mathrm{Ch:}$ HEDTA. Similar results were also reported by Syed et al., (2016) and Kulhare et al., (2017). Better performance of Zn EDTA as compared to $\mathrm{ZnSO}_{4} \cdot 7 \mathrm{H}_{2} \mathrm{Oin}$ bajra was reported by Panda and Doddamani (2018).

Foliar spray of $0.5 \%$ TNAU chelated $\mathrm{Zn}$ formulations and soil application of $1.5 \mathrm{~kg} \mathrm{Zn}$ $\mathrm{ha}^{-1}$ as TNAU Zn EDTA recorded significantly higher and comparable yield among themselves. The results revealed that foliar spray of $\mathrm{Zn}$ chelates performed better when compared to soil application of the same.

The grain yields registered in the treatments soil application of $0.75 \mathrm{~kg} \mathrm{Zn} \mathrm{ha}{ }^{-1}$ as TNAU Zn EDTA $\left(\mathrm{T}_{3}\right), 1.5 \mathrm{~kg} \mathrm{Zn} \mathrm{ha}^{-1}$ as TNAU Zn citrate $\left(\mathrm{T}_{6}\right), 1.5 \mathrm{~kg} \mathrm{Zn} \mathrm{ha}^{-1}$ as commercial $\mathrm{Zn}$ EDTA $\left(\mathrm{T}_{8}\right), 7.5 \mathrm{~kg} \mathrm{Zn} \mathrm{ha}{ }^{-1}$ as $\mathrm{ZnSO}_{4}\left(\mathrm{~T}_{2}\right)$ and foliar spray of $0.5 \% \quad \begin{array}{llll}\mathrm{ZnSO}_{4} & \left(\mathrm{~T}_{9}\right) \text { were }\end{array}$ statistically comparable. Significantly lowest value $\left(5867 \mathrm{~kg} \mathrm{ha}^{-1}\right)$ was registered in control (NPK alone $-\mathrm{T}_{1}$ ) and it remained on par with $0.75 \mathrm{~kg} \mathrm{Zn} \mathrm{ha}^{-1}$ as TNAU Zn citrate $\left(\mathrm{T}_{5}\right)$ and $0.75 \mathrm{~kg} \mathrm{Zn} \mathrm{ha}^{-1}$ as commercial Zn EDTA $\left(\mathrm{T}_{7}\right)$.

Table.1 Initial soil sample characteristics

\begin{tabular}{|c|c|c|}
\hline $\mathrm{pH}$ & & 8.07 \\
\hline $\mathrm{EC}$ & $\mathrm{dSm}^{-1}$ & 0.24 \\
\hline Organic Carbon & $\mathrm{g} \mathrm{kg}^{-1}$ & 4.79 \\
\hline Available N & $\mathrm{kg} \mathrm{ha}^{-1}$ & 134 \\
\hline Available P & & 16.7 \\
\hline Available K & & 657 \\
\hline DTPA-Fe & \multirow{2}{*}{$\mathrm{mg} \mathrm{kg}^{-1}$} & 2.27 \\
\hline DTPA-Zn & & 0.60 \\
\hline DTPA-Mn & & 5.08 \\
\hline DTPA & & 0.89 \\
\hline DTPA-Cu & & \\
\hline
\end{tabular}


Table.2 Effect of $\mathrm{Zn}$ formulations on yield, $\mathrm{Zn}$ content and uptake at late vegetative stage of maize

\begin{tabular}{|c|c|c|c|c|}
\hline \multirow[t]{2}{*}{ Treatments } & \multicolumn{2}{|c|}{ Late vegetative stage } & \multirow{2}{*}{$\begin{array}{c}\text { Grain } \\
\text { yield } \\
\left(\text { kg ha }^{-1}\right)\end{array}$} & \multirow{2}{*}{$\begin{array}{c}\text { Stover } \\
\text { yield } \\
\left(\mathrm{kg} \mathrm{ha}^{-1}\right)\end{array}$} \\
\hline & $\begin{array}{l}\mathrm{Zn} \text { content } \\
\left(\mathrm{mg} \mathrm{kg}^{-1}\right)\end{array}$ & $\begin{array}{l}\text { Zn uptake } \\
\left(\mathrm{g} \mathrm{ha}^{-1}\right)\end{array}$ & & \\
\hline $\mathbf{T}_{1}$-Control (NPK alone) & 39.3 & 260 & 5867 & 10088 \\
\hline $\mathrm{T}_{2-7.5} \mathrm{~kg} \mathrm{Zn} \mathrm{ha}^{-1}$ as $\mathrm{ZnSO}_{4}$ & 41.1 & 297 & 6423 & 11198 \\
\hline$T_{3-0.75} \mathrm{~kg} \mathrm{Zn} \mathrm{ha}^{-1}$ as TNAU Zn EDTA & 42.2 & 314 & 6547 & 11483 \\
\hline $\mathrm{T}_{4}-1.5 \mathrm{~kg} \mathrm{Zn} \mathrm{ha}^{-1}$ as TNAU Zn EDTA & 43.0 & 347 & 6985 & 12352 \\
\hline $\mathrm{T}_{5}-\mathbf{0 . 7 5} \mathrm{kg} \mathrm{Zn} \mathrm{ha}^{-1}$ as TNAU Zn citrate & 40.1 & 273 & 5937 & 10415 \\
\hline $\mathrm{T}_{6}-1.5 \mathrm{~kg} \mathrm{Zn} \mathrm{ha}^{-1}$ as TNAU Zn citrate & 41.6 & 303 & 6452 & 11408 \\
\hline$T_{7}-0.75 \mathrm{~kg} \mathrm{Zn} \mathrm{ha}^{-1}$ as commercial Zn EDTA & 39.6 & 265 & 5910 & 10355 \\
\hline $\mathbf{T}_{8}-1.5 \mathrm{~kg} \mathrm{Zn} \mathrm{ha}^{-1}$ as commercial Zn EDTA & 41.5 & 287 & 6182 & 10662 \\
\hline $\mathrm{T}_{9}$-Foliar spray of $0.5 \% \mathrm{ZnSO}_{4}{ }^{*}$ & 42.6 & 295 & 6377 & 11067 \\
\hline $\mathrm{T}_{10}$-Foliar spray of $0.5 \%$ TNAU Zn EDTA ${ }^{*}$ & 44.8 & 365 & 7158 & 12741 \\
\hline $\mathrm{T}_{11}$-Foliar spray of $0.5 \%$ TNAU Zn citrate & 44.1 & 346 & 6962 & 12115 \\
\hline 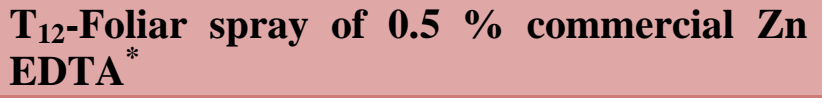 & 43.2 & 336 & 6777 & 12052 \\
\hline SEd & 1.2 & 15 & 287 & 504 \\
\hline $\mathrm{CD}(\mathrm{P}=\mathbf{0 . 0 5})$ & 2.5 & 31 & 595 & 1044 \\
\hline
\end{tabular}

*thrice on 30,40 and 50 DAS

Table.3 Effect of Zn formulations on $\mathrm{Zn}$ content and uptake at harvest stage of maize

\begin{tabular}{|c|c|c|c|c|}
\hline \multirow[t]{2}{*}{ Treatments } & \multicolumn{2}{|c|}{ Grain } & \multicolumn{2}{|c|}{ Stover } \\
\hline & $\begin{array}{l}\text { Content } \\
\left(\mathrm{mg} \mathrm{kg}^{-1}\right)\end{array}$ & $\begin{array}{l}\text { Uptake } \\
\left(\mathrm{g} \mathrm{ha}^{-1}\right)\end{array}$ & $\begin{array}{l}\text { Content } \\
\left(\mathrm{mg} \mathrm{kg}^{-1}\right)\end{array}$ & $\begin{array}{l}\text { Uptake } \\
\left(\mathrm{g} \mathrm{ha}^{-1}\right)\end{array}$ \\
\hline$T_{1}$-Control (NPK alone) & 26.5 & 143 & 30.8 & 287 \\
\hline $\mathrm{T}_{2-7.5} \mathrm{~kg} \mathrm{Zn} \mathrm{ha}^{-1}$ as $\mathrm{ZnSO}_{4}$ & 28.4 & 166 & 33.8 & 354 \\
\hline$T_{3}-0.75 \mathrm{~kg} \mathrm{Zn} \mathrm{ha}^{-1}$ as TNAU Zn EDTA & 28.5 & 172 & 34.4 & 365 \\
\hline $\mathrm{T}_{4}-1.5 \mathrm{~kg} \mathrm{Zn} \mathrm{ha}^{-1}$ as TNAU Zn EDTA & 29.5 & 192 & 35.8 & 416 \\
\hline $\mathrm{T}_{5}-0.75 \mathrm{~kg} \mathrm{Zn} \mathrm{ha}^{-1}$ as TNAU Zn citrate & 26.8 & 146 & 31.8 & 302 \\
\hline $\mathrm{T}_{6}-1.5 \mathrm{~kg} \mathrm{Zn} \mathrm{ha}^{-1}$ as TNAU Zn citrate & 29.1 & 173 & 34.2 & 361 \\
\hline$T_{7-0.75} \mathrm{~kg} \mathrm{Zn} \mathrm{ha}^{-1}$ as commercial Zn EDTA & 26.6 & 145 & 31.1 & 298 \\
\hline $\mathrm{T}_{8}-1.5 \mathrm{~kg} \mathrm{Zn} \mathrm{ha}^{-1}$ as commercial Zn EDTA & 28.6 & 161 & 33.2 & 327 \\
\hline $\mathrm{T}_{9}$-Foliar spray of $0.5 \% \mathrm{ZnSO}_{4}{ }^{*}$ & 30.1 & 172 & 33.4 & 341 \\
\hline $\mathrm{T}_{10}$-Foliar spray of $0.5 \%$ TNAU Zn EDTA ${ }^{*}$ & 31.1 & 205 & 36.5 & 436 \\
\hline T $_{11}$-Foliar spray of $0.5 \%$ TNAU Zn citrate ${ }^{*}$ & 32.4 & 207 & 35.1 & 396 \\
\hline $\mathrm{T}_{12}$-Foliar spray of $0.5 \%$ commercial Zn EDTA ${ }^{*}$ & 30.5 & 190 & 34.7 & 388 \\
\hline SEd & 0.8 & 13 & 1.0 & 26 \\
\hline $\mathrm{CD}(\mathrm{P}=\mathbf{0 . 0 5})$ & 1.7 & 26 & 2.0 & 54 \\
\hline
\end{tabular}

*thrice on 30, 40 and 50 DAS 
With respect to stover yield, the treatment foliar spray of $0.5 \%$ TNAU Zn EDTA $\left(\mathrm{T}_{10}\right)$ recorded significantly higher stover yield of $12741 \mathrm{~kg} \mathrm{ha}^{-1}$ (Table 2) Foliar spray of $0.5 \%$ chelated $\mathrm{Zn}$ formulations and soil application of $1.5 \mathrm{~kg} \mathrm{Zn} \mathrm{ha}^{-1}$ as TNAU $\mathrm{Zn}$ EDTA registered comparable stover yields. Stover yields observed with soil application of 0.75 $\mathrm{kg} \mathrm{Zn} \mathrm{ha}{ }^{-1}$ as TNAU Zn EDTA $\left(\mathrm{T}_{3}\right)$ was statistically on par with soil application of 1.5 $\mathrm{kg} \mathrm{Zn} \mathrm{ha}{ }^{-1}$ as TNAU $\mathrm{Zn}$ citrate $\left(\mathrm{T}_{6}\right)$ and commercial Zn EDTA( $\left.\mathrm{T}_{8}\right)$, soil (7.5 kg Zn ha $\left.{ }^{1}\right)$ and foliar application $(0.5 \%)$ of recommended quantity of $\mathrm{ZnSO}_{4}$. Lowest stover yield of $10088 \mathrm{~kg} \mathrm{ha}^{-1}$ was noticed in control (NPK alone $-\mathrm{T}_{1}$ ). The results are in line with the findings of Ortega-Blu and Molina-Roco (2007) who reported higher corn dry matter with Zn EDTA as compared to $\mathrm{ZnSO}_{4}$.

\section{$\mathrm{Zn}$ content and uptake at late vegetative stage}

$\mathrm{Zn}$ content in maize plant at late vegetative stage varied from 39.3 to $44.8 \mathrm{mg} \mathrm{kg}^{-1}$ (Table 2). The treatment foliar spray of $0.5 \%$ TNAU Zn EDTA $\left(\mathrm{T}_{10}\right)$ recorded significantly higher $\mathrm{Zn}$ content and control (NPK alone $-\mathrm{T}_{1}$ ) recorded lowest $\mathrm{Zn}$ content. This is in agreement with the findings of Teixeira et al., (2019) who reported that $\mathrm{Zn}$ content and $\mathrm{Zn}$ uptake in the Mombasa grass was directly proportional to the rate of foliar applied chelated $\mathrm{Zn}$, contributing to the yield of better quality forage. The improvement in the $\mathrm{Zn}$ concentration and uptake observed in this experiment comparing $\mathrm{ZnSO} 4$ and $\mathrm{Zn}$-EDTA, is similar to that reported by Gangloff et al., (2002). Foliar spray of $0.5 \% \mathrm{Zn}$ formulations and soil application of $1.5 \mathrm{~kg} \mathrm{Zn} \mathrm{ha}{ }^{-1}$ as TNAU Zn EDTA recorded significantly higher and comparable $\mathrm{Zn}$ content. With respect to $\mathrm{Zn}$ uptake at late vegetative stage, the treatment foliar spray of $0.5 \%$ TNAU Zn EDTA $\left(T_{10}\right)$ registered significantly higher $\mathrm{Zn}$ uptake of $365 \mathrm{~g} \mathrm{ha}^{-1}$ (Table 2). Zn uptake in the treatments, foliar spray of $0.5 \%$ chelated $\mathrm{Zn}$ formulations and soil application of $1.5 \mathrm{~kg}$ $\mathrm{Zn} \mathrm{ha}^{-1}$ as TNAU Zn EDTA were comparable. Lowest Zn uptake of $260 \mathrm{~g} \mathrm{ha}^{-1}$ was observed in control (NPK alone $-\mathrm{T}_{1}$ ).

\section{Zn content and uptake at harvest stage}

Grain Zn content ranged from 26.5 to $32.4 \mathrm{mg}$ $\mathrm{kg}^{-1}$ (Table 3). Marked variation in grain $\mathrm{Zn}$ content was observed among the treatments. Significantly highest grain Zn content was observed in the treatment foliar spray of $0.5 \%$ TNAU Zn citrate $\left(\mathrm{T}_{11}\right)$ which was on par with the treatment foliar spray of $0.5 \%$ TNAU $\mathrm{Zn}$ EDTA $\left(\mathrm{T}_{10}\right)$. Both $\mathrm{Zn}$ concentration and $\mathrm{Zn}$ content in plant shoots were higher in the presence of citrate than in the absence (Chairidchai and Ritchie, 1993). The treatments foliar spray of $0.5 \%$ commercial $\mathrm{Zn}$ EDTA and $\mathrm{ZnSO}_{4}$, soil application of 1.5 $\mathrm{kg} \mathrm{Zn} \mathrm{ha}{ }^{-1}$ as $\mathrm{Zn}$ EDTA and TNAU Zn citrates recorded comparable grain $\mathrm{Zn}$ content. Grain Zn content was lowest in control (NPK alone $-\mathrm{T}_{1}$ ) which was on par with $0.75 \mathrm{~kg} \mathrm{Zn} \mathrm{ha}^{-1}$ as TNAU Zn citrate $\left(\mathrm{T}_{5}\right)$ and commercial $\mathrm{Zn}$ EDTA $\left(\mathrm{T}_{7}\right)$. Grain $\mathrm{Zn}$ uptake varied from 143 to $207 \mathrm{~g} \mathrm{ha}^{-1}$. The highest value was recorded in the treatment foliar spray of $0.5 \%$ TNAU Zn citrate $\left(\mathrm{T}_{11}\right)$. Grain $\mathrm{Zn}$ uptake in the treatments foliar spray of $0.5 \%$ chelated $\mathrm{Zn}$ formulations and soil application of $1.5 \mathrm{~kg} \mathrm{Zn} \mathrm{ha}{ }^{-1}$ as TNAU Zn EDTA were comparable. These results are in agreement with the findings of Verma et al., (2015), Islam et al., (2016) and Kulhare et al., (2017). Zn uptake in the treatments, soil application of $1.5 \mathrm{~kg} \mathrm{Zn} \mathrm{ha}^{-1}$ as $\mathrm{Zn}$ citrate $\left(\mathrm{T}_{6}\right)$ and commercial $\mathrm{Zn}$ EDTA $\left(\mathrm{T}_{8}\right)$, soil application of $0.75 \mathrm{~kg} \mathrm{Zn} \mathrm{ha}^{-1}$ as TNAU Zn EDTA $\left(\mathrm{T}_{3}\right), 7.5 \mathrm{~kg} \mathrm{Zn} \mathrm{ha}^{-1}$ as $\mathrm{ZnSO}_{4}\left(\mathrm{~T}_{2}\right)$ and foliar spray of $0.5 \% \quad \mathrm{ZnSO}_{4}\left(\mathrm{~T}_{9}\right)$ were statistically on par. Lowest grain $\mathrm{Zn}$ uptake of $143 \mathrm{~g} \mathrm{ha}^{-1}$ was noticed in control (NPK alone $\left.-\mathrm{T}_{1}\right)$. 
Stover $\mathrm{Zn}$ content was in the range of 30.8 to $36.5 \mathrm{mg} \mathrm{kg}^{-1}$ (Table 3). Stover $\mathrm{Zn}$ content was significantly highest with foliar spray of $0.5 \%$ TNAU Zn EDTA $\left(\mathrm{T}_{10}\right)$ and this remained comparable with foliar spray of $0.5 \%$ TNAU $\mathrm{Zn}$ citrate $\left(\mathrm{T}_{11}\right)$ and $0.5 \%$ commercial $\mathrm{Zn}$ EDTA $\left(\mathrm{T}_{12}\right)$, soil application of $1.5 \mathrm{~kg} \mathrm{Zn} \mathrm{ha}^{-1}$ as TNAU Zn EDTA $\left(\mathrm{T}_{4}\right)$. Stover $\mathrm{Zn}$ content was lowest $\left(30.8 \mathrm{mg} \mathrm{kg}^{-1}\right)$ in the treatment control (NPK alone $-\mathrm{T}_{1}$ ). Stover $\mathrm{Zn}$ uptake was significantly highest (436 $\left.\mathrm{g} \mathrm{ha}^{-1}\right)$ in the treatment foliar spray of $0.5 \%$ TNAU $\mathrm{Zn}$ EDTA $\left(\mathrm{T}_{10}\right)$. Foliar spray of $0.5 \%$ chelated $\mathrm{Zn}$ formulations and soil application of $1.5 \mathrm{~kg} \mathrm{Zn}$ $\mathrm{ha}^{-1}$ as TNAU Zn EDTA recorded comparable stover Zn uptake values. Lima et al., (2014) observed that $\mathrm{Zn}$ fertilization via soil as well as foliar can be adequate strategies to supply of $\mathrm{Zn}$ to maize plants. Control (NPK alone $\mathrm{T}_{1}$ ) registered the lowest stover $\mathrm{Zn}$ uptake of $287 \mathrm{~g} \mathrm{ha}^{-1}$. The increase in both grain and straw yield with application of Zn-EDTA might be due to the relatively greater amount of $\mathrm{Zn}$ uptake compared with $\mathrm{ZnSO}_{4}$ application. These results are in agreement with the findings of Karak et al., (2005) who reported that chelated $\mathrm{Zn}$ was the most efficient source of $\mathrm{Zn}$ for lowland rice production in calcareous soil. Also, $\mathrm{Zn}$ mobilisation efficiency was higher with $\mathrm{Zn}$ EDTA than with $\mathrm{ZnSO}_{4}$ for $\mathrm{Zn}$ uptake by grain and straw (Naik and Das, 2008). The results are in agreement with Takkar and Singh (1989).

Percentage yield increase due to foliar spray of $0.5 \%$ TNAU Zn EDTA and $0.5 \%$ TNAU $\mathrm{Zn}$ citrate formulations respectively were 22.0 and $18.7 \%$ over control, 11.4 and $8.38 \%$ over $\mathrm{ZnSO}_{4}$ soil application and 12.3 and 9.17 $\%$ over $\mathrm{ZnSO}_{4}$ foliar spray. The treatments foliar spray of $0.5 \%$ TNAUZn EDTAand0.5 $\%$ TNAUZn citrate thrice on 30,40 and 50 DAS recorded higher grain and stover yield as well as $\mathrm{Zn}$ content and $\mathrm{Zn}$ uptake over all other treatments.

\section{References}

Alloway. B.J. (ed.). 2008. Micronutrient Deficiencies in Global Crop Production. Springer, Netherlands.

Chairidchai, P. and G.S.P. Ritchie. 1993. The effect of citrate and $\mathrm{pH}$ on zinc uptake by wheat. Agron. J. 85: 322-328.

Gangloff, W., D. G. Westfall, G. A. Peterson, and J. J. Mortvedt. 2002. Relative availability coefficients of organic and inorganic $\mathrm{Zn}$ fertilizers. J. Plant Nutr. 25: 259-273.

Islam, M.R., N.Yesmin, M.Malika, A.Huda and M.M. Rahman. 2016. Effect of zinc supplied from two different sources on the growth, yield and zinc uptake of rice (cv. BRRI dhan49). Asian Australas. J Biosci. Biotechnol. 1(2): 230- 234.

Jackson, M. 1973. Methods of chemical analysis: Prentice Hall of India (Pvt.) Ltd., New Delhi.

Kabata-Pendias, A. 2000. Trace elements in soils and plants, 3rd edn. CRC, Boca Raton.

Karak, T., U.K. Singh, S. Das, D.K. Das and Y. Kuzyakov. 2005. Comparative efficacy of ZnSO4 and Zn-EDTA application for fertilization of rice. Arch Agron Soil Sci. 51: 253-264.

Khalid, F., M. Tahir, N. Fiaz and M. A. Nadeem and S. M. W. Gillani. 2013. Hybrid maize response to assorted chelated and non chelated foliar applied zinc rates. Journal of Agricultural Technology. 9(2): 295-309.

Klug, A. and D. Rhodes. 1987. 'Zinc fingers': a novel protein motif for nucleic acid recognition. Trends Biochem Sci. 12: 464-469.

Kulhare, P.S., G.S. Tagore and G.D. Sharma. 2017. Effect of foliar spray and sources of zinc on yield, zinc content and uptake by rice grown in a Vertisol of central India. International Journal of Chemical Studies. 5(2): 35-38. 
Lima, P., A. Gisele, L.B. Ponte and A.B. Chico. 2014. An investigation of zinc uptake by maize plants after fertilization with soil and foliage. African Journal of Environmental Economics and Management. 2(1):177-180.

Loeppert, R. H. 1986. Reactions of iron and carbonates in calcareous soils. J. Plant Nutr. 9: 195-214.

MacNacidhe, F.S. and G.A. Fleming. 1988. A response in spring cereals to foliar sprays of zinc in Ireland. Irish Journal of Agricultural research, 27: 91-97.

Naik, S.K. and D.K.Das. 2008. Relative performance of chelated zinc and zinc sulphate for lowland rice (Oryza sativa L.). NutrCycl Agroecosyst. 81: 219-227.

Ortega-Blu R. and M. Molina-Roco. 2007. Comparison between sulfates and chelated compounds as sources of zinc and iron in calcareous soils. Agrociencia. 41: 491-502.

Panda, B. and M.B. Doddamani. 2018. Efficiency of $\mathrm{ZnSO}_{4} .7 \mathrm{H}_{2} \mathrm{O}$ and $\mathrm{Zn}$ EDTA in improving morphology and yield of bajra (Pennisetum glaucum L.). J. Farm Sci. 31(4):397-400.

Panse, V. G. and Sukhatme, P. V. 1978. Statistical methods for agricultural workers. Statistical methods for agricultural workers.(Ed. 3).
Syed, T., B.M. Anwar, H. Ashaq, M.A. Ganai and N.A. Teli. 2016. Effect of levels and sources of zinc on growth, yield and economics of rice (Oryza sativa) under temperate conditions. Indian Journal of Agronomy. 61(2): 186-190.

Takkar, P.N. and T.Singh.1989. Zinc nutrition of rice as influenced by rates of gypsum and $\mathrm{Zn}$ fertilization of alkali soil. $\mathbf{J}$ Indian Soc Soil Sci. 70: 442-450.

Teixeira, N.M., R. Heinrichs, C.S.B. Bonini, J. Afzal, G.C. Meirelles, C.V.S. Filho and Adonis Moreira. 2019. Chelated zinc leaf application on nutrients concentration and yield of Mombasa grass. Journal of plant nutrition. 42(1): 89-98.

Vempati, R. K., and R. H. Loeppert. 1988. Chemistry and mineralogy of $\mathrm{Fe}$ containing oxides and layer silicates in relation to plant available iron. J. Plant Nutr. 11: 1557-1574.

Verma, V.K., R.N. Meena, S.P. Maurya, S. Bahadur, A. Gautam and Maniram. 2015. Effect of sources of zinc and various crop establishment methods on growth, yield and yield attributes of rice (Oryza sativa L.) in eastern U.P. Ecology, Environment and Conservation. (21): 283- 287.

\section{How to cite this article:}

Malathi, P. 2021. Influence of Zinc Chelates on Yield and Zn Uptake by Maize. Int.J.Curr.Microbiol.App.Sci. 10(01): 397-403. doi: https://doi.org/10.20546/ijcmas.2021.1001.048 